\title{
UM MESTRE: JOÃO JOSÉ PLANELLA
}

\author{
Núncia Santoro de Constantino*
}

Desaparecido o MESTRE, pretendo apenas registrar percepções e lembranças que são compartilhadas entre os professores do IFCH, a julgar pelos depoimentos e impressões externados durante décadas.

Planella foi professor-guia, com seu interesse pela aprendizagem dos alunos a quem soube estimular a capacidade criadora e de quem obteve o reconhecimento como autoridade em História. Foi colega respeitado e amigo querido. Isso é o mínimo que se pode dizer, em tempos quando não é muito considerada a possibilidade da pessoa ter e evidenciar um conjunto admirável de qualidades. Nosso decano foi erudito, pessoa religiosa na teoria e na prática, representante legítimo de instituição católica da qual não só vestiu como suou a camiseta.

Em 1964, mais alunos ingressavam na PUC para freqüentar o Curso de História. Formávamos grupo diminuto e nos tornamos grupo coeso, de cumplicidade sempre lembrada. Nossa primeira experiência acadêmica deu-se através do Prof. Planella. E foi sem dúvida a experiência mais marcante.

Desde o primeiro contato ficou claro que tínhamos um PROFESSOR, cuja imponência não se limitava ao avantajado físico ou à voz que abafava sons desnecessários em sala de aula. Constataríamos que não seriam necessárias as reprimendas ou admoestaçōes, quando muito viria

* Professora do Departamento de História - IFCH-PUCRS. 
a ocorrer uma sútil observação irônica que suspendia entusiasmos fora de hora. Era efeito relâmpago mas de repercussão duradoura.

As aulas eram expositivas, as palavras escandidas no melhor português, com auxílio de esquema no quadro-negro, em primorosa caligrafia. Porque no prédio da Praça Don Sebastião o quadro ainda era negro. E desenrolava-se aquele espetáculo de comunicação, capaz de conter adolescentes barulhentos e irreverentes como éramos, como agora são e serão os alunos nos primeiros tempos de universidade.

Depois aconteceria o despertar da paixão pela História, o comprometimento de uma grande e atenta maioria. Paixão imediata, já com Heródoto narrando as guerras persas e antevendo o conflito entre Ocidente e Oriente. Nas digressões do Pai da História percebeu-se o historiador humanista, legando à posteridade ações do HOMEM.

Para fortalecer nosso contato com a História, Planella apresentava as Guerras do Peloponeso e a superioridade de Tucidedes, cujo nome pronunciava lentamente, com indisfarçável admiração. Lembrava que o ateniense dera um passo à frente em direção à ciência histórica, demonstrando preocupação com a verdade das coisas passadas. Logo o Mestre começava a insistir no compromisso do historiador com a verdade, incentivando a crítica. A relação de amor dos seus novos alunos com a História prometia ser duradoura quando apontada Xenofonte e Políbio.

No decorrer do curso, Planella estaria sempre presente. Ministrava outras disciplinas, além da Introdução aos Estudos Históricos. Mesmo que sua presença não fosse formal em sala de aula, permanecia MESTRE cercado de discípulos nos corredores, na sala de professores. Acompanhava e orientava progressos. Era a pessoa a quem se recorria.

À medida que avançávamos, íamos compreendendo que nossa competência precisava ir além de manter viva a memória dos acontecimentos do passado. Que nada significa comentar feitos exemplares. Pelo Mestre fomos suficientemente advertidos de que nunca são semelhante as condições em que se produzem os atos humanos. Daí que lições de História são inóquas porque a mesma não se repete. Cumprimentávamos Seignobos, travávamos conhecimento com Fustel de Coulanges. Éramos desafiados a entender a relação entre Vico e Croce, antes de ouvir falar em Bloch, Febvre ou Braudel. Os fundamentos teóricos que íamos adquirindo decorriam sobretudo da imensa erudição do Mestre e de sua capacidade de organizar o ensino. 
Planella acompanhou milhares de alunos, muitos deles depois professores da PUC. Preservou-os do contágio que significa a exploração ideológica da História. Nosso Departamento contou sempre com uma maioria de professores que admite, como função teórica da História, o movimento da sociedade no passado e, como função social, a organização deste passado em função do presente. Como corpo docente não privilegiamos a ideologia e, por isso, não criamos obstáculos às concepçọes da ciência histórica. Penso que nossa boa reputação foi firmada nessa linha graças à orientação de quem foi MESTRE de todos nós por mais de trinta anos, de quem fez ESCOLA. Lembraremos sua ironia ao diletantismo e de quanto nos poupou da heráldica, da genealogia, dos infindáveis elencos dinásticos, das estratégias minuciosas de batalhas.

Planella emprestou a gerações ferramentas que permitem estimular a realização pessoal, que permitem avançar na interpretação do mundo para transformá-lo. Com Planella a História também nos proporciona prazer.

Como colega continuou sendo MESTRE. Toda e qualquer dúvida poderia ser dirimida através de sua segura e desinteressada orientação. Permanente fonte de consulta, ajudou um corpo docente a qualificar-se em cursos de Mestrado e Doutorado. Seu auxílio acontecia desde a escolha dos temas de pesquisa, com indicações bibliográficas, até a leitura da síntese final, quando corrigia inclusive deslizes gramaticais.

Se foi colocado em patamar superior pelos seus colegas, isso não aconteceu somente pelas suas qualidades profissionais. A dimensão da Pessoa contribuiu sobremaneira. Acessível a todos, capaz de entender nossas queixas, incapaz de nutri-las. Incapaz de apontar falhas alheias. Irônico, humorista, propenso a boas risadas, companheiro agradável fora dos muros.

O Amigo adoeceu quando deveria completar e publicar os resultados de pesquisa historiográfica, a que dedicou o tempo em que não ensinava, nas últimas décadas. Talvez ainda possamos tirar proveito do seu estudo inacabado; surgem formas para resolver em parte essa questão. Impossível é neutralizar o sentimento de orfandade de um corpo docente a quem sempre demonstrou amizade.

A revelação do seu imenso carinho aconteceu, mais uma vez, em visita que lhe foi feita, na cidade de Pelotas. Com grande dificuldade para 
ouvir e falar, ansiava para prosseguir o trabalho iniciado. Sentia saudades dos coletas e da convivência no IFCH. Emocionou-se às lágrimas quando da despedida. A outros colegas também disse que nossas passagens breves pela Praça Piratinino de Almeida eram momentos de alegria.

Mestre e Amigo de todos, dupla falta. Imensa perda, em parte compensada pelo legado. Reconhecimento de posição inigualável em nosso corpo docente. Saudade. 